\title{
First Report of Mesocriconema sphaerocephalum (Taylor, 1936) Loof, 1989 Associated with Bell Pepper (Capsicum annuum) in Egypt
}

\section{Zafar A. Handoo', Mihail R. Kantor ${ }^{1}$, Mostafa M.A. Hammam², Moawad M.M. Mohamed $^{2}$ and Mahfouz M. M. Abd-Elgawad ${ }^{2}$}

\author{
1 Mycol. and Nematol. Genetic Diversity and Biol. Lab., USDA, ARS, Northeast Area, Beltsville \\ Agric.Res. Center, Beltsville, MD 20705, USA \\ 2 Plant Pathology Dept., National Research Centre, EI-Behooth St., Dokki 12622, Giza, Egypt.
}

Corresponding author email: mahfouzian2000@yahoo.com

\begin{abstract}
Ring nematodes of the genus, Mesocriconema are a group of polyphagous, migratory root-ectoparasites of plants. In a nematological survey of three governorates in Egypt, Mesocriconema sphaerocephalum (Taylor, 1936) Loof, 1989 was isolated from the rhizosphere of soil samples in five bell pepper (Capsicum annuum L.) fields, as a new host record, at Badr Centre, El-Beheira governorate. Mesocriconema sphaerocephalum specimens were extracted from 5 out of $45(11.1 \%)$ soil samples with a population density up to 23 individuals/250 g soil. Morphological and morphometrical analysis of females and juveniles were used for species identification. This species has been previously reported from Egypt on other hosts. Nevertheless, this is the first report of $M$. sphaerocephalum associated with pepper plants. Additional information on the distribution, importance, and status of this phytoparasite is presented.
\end{abstract}

Keywords: Host plant, morphology, ring nematode, Egypt, species description, survey.

\section{INTRODUCTION}

A few plant parasitic nematode (PPN) groups have received insufficient attention compared with other species especially concerning their pathogenicity and damage to the host plants. Among them is the group of ring nematodes (Abd-Elgawad, 2020). It is well known that the Criconematidae family is a taxonomy commonly referred to as ring nematodes, due to the transversal annulation of the cuticle; typical wide cuticular annulation. All species of this group can parasitize broad range of host plants including monocotyledonous and dicotyledonous, herbaceous, and woody plants worldwide (PerazaPadilla, 2014). Several criconematids have become notorious pests of crops. They can not only damage plant roots (Westerdahl \& Duncan 2015), but also predispose them to the other biotic stresses (Inserra et al., 2014 and Maria et al., 2018a,b). Moreover, some of them were involved in the decline of cultivated crops (Nath et al., 2008 and Maria et al., 2020). Additionally, this remarkable group has been reported associated with Citrus sp. In 
Morocco; Zea mays L. in Kenya; Brassica oleracea L., Allium porrum L. and Lactuca sativa L. in Madagascar (Luc, 1970); coffee plantations in El Salvador (Raski \& Golden, 1965); apricot in USA (Mckenry et al., 1990); peach and apple in Spain (Escuer \& Palomo, 1991); vineyards in Italy (Coiro et al., 1991); avocado, mango and tamarind in Spain (Castillo \& Gómez, 1993); Mussa sp. in Jordan (Yousef \& S'Jacob, 1994); peach in Mexico (Luna-Guerrero et al., 2011); barley, wheat and sugar beet in the Slovak Republic (Šály, 1976); forage legumes at Alachua County, Florida, USA (Abd-Elgawad et al., 2018), and mulberry (Morus alba L.) trees in Costa Rica (Peraza-Padilla, 2014), and others.

Considering the above-mentioned status of the Criconematidae, characterizing/identifying its species as well as knowledge of their occurrence, distribution, and pathogenicity is important since they may cause considerable damage to many economically important crops in Egypt (Adam et al., 2013; Handoo et al., 2015 and Ibrahim et al., 2000, 2010). Generally, nematologists have recorded more than 50 genera and 160 species of PPNs and free-living nematodes associated with many cultivated plants, grasses and weeds in Egypt (Ibrahim et al., 2010; Ibrahim \& Handoo, 2016 and Mohamed et al., 2017). During our nematode inventory survey, a population of Mesocriconema was detected in the rhizosphere of bell pepper plants among other PPN species. As Mesocriconema was never associated with pepper from Egypt, the present work was dedicated to identifying the species status based on the morphological and morphometrical characters in the species-specific identification key of $M$. sphaerocephalum, the morphology characterization data of this population were compared with the existing species of the genus. Therefore, the paper describes $M$. sphaerocephalum and provides a morphological characterization of it to elucidate important morphological details.

\section{MATERIALS AND METHODS}

The nematological survey was carried out in El-Ismalia, El-Beheira, and El-Giza governorates (Fig. 1) to detect new parasites associated with pepper. A total of 45 soil and root composite samples were collected by a shovel (ca $30 \mathrm{~cm}$ diam. to a depth of 25 $\mathrm{cm}$ ) from the rhizosphere region of plants that appeared relatively unhealthy; i.e. with suspected nematode disease symptoms such as poor growth, stunting, wilting, and yellowing. Three subsamples representing one Feddan $\left(4200 \mathrm{~m}^{2}\right)$ were randomly collected and mixed to form a composite sample of about $1 \mathrm{Kg}$ soil per a pepper field for fifteen fields in a governorate. The soil type in each of the three governorates was sandy, loamy sand, or sandy loam. During sampling period, in August and September (fall season), there was no rain, clear sky, day temperature was $32-41^{\circ} \mathrm{C}$, night temperature was $18-23^{\circ} \mathrm{C}$, and soil was drip irrigated for pepper plants which were grown under the traditional farming system for production of pepper in Egypt (Zayed et al., 2017). Roots were washed free of soil and examined for galling where root-knot nematodes were extracted and identified according to Ibrahim et al. (2000). Using another technique followed by the latter authors for extracting migratory and ectoparasitic nematodes, roots having lesions were fragmented into small pieces and left in water for 36-48 h to extract such nematodes. 
Fig. 1 Soil samples collection area map.

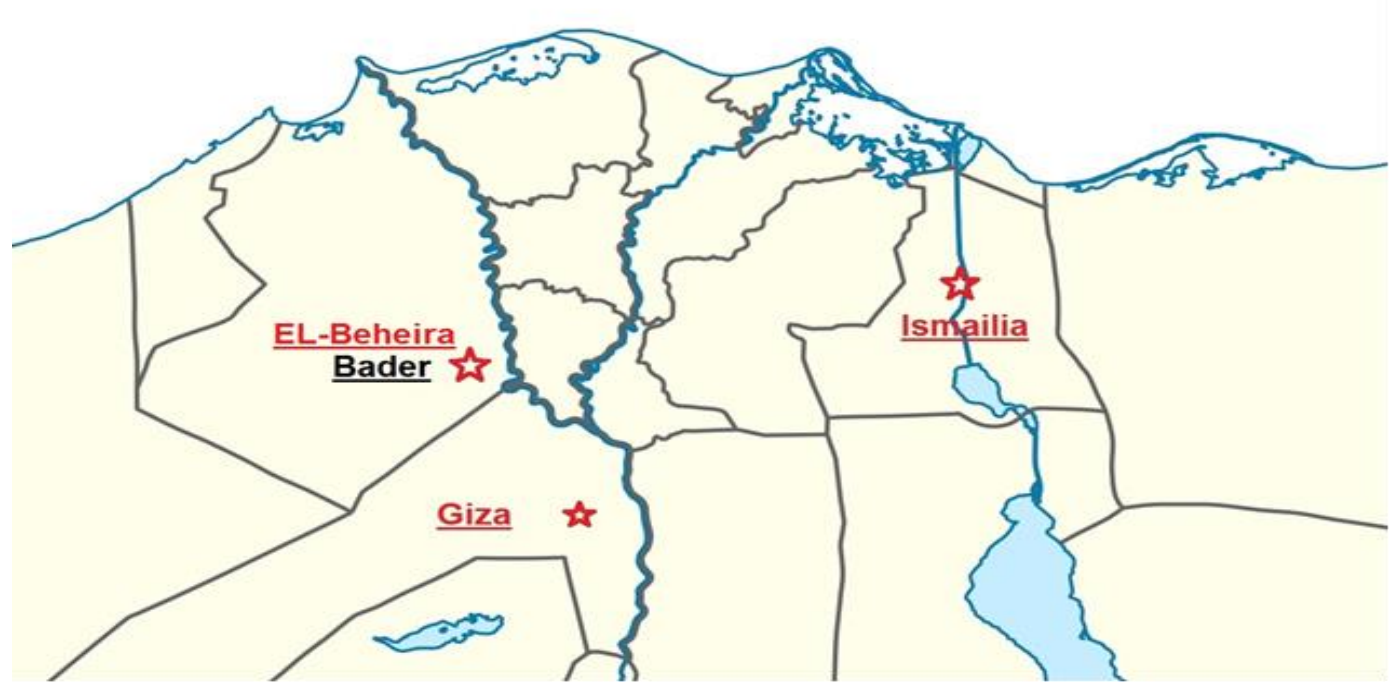

About one-fourth of each composite sample (exactly $250 \mathrm{~g}$ soil) was extracted using Cobb's wet-sieving and centrifugal sugar flotation techniques (Ayoub, 1980). The used sieves were US Standard Sieve Series of 100, 200, and 325 mesh with openings of 149, 74 , and $44 \mu$, respectively. The extracted PPNs were fixed in 5\% formaldehyde solution, processed to anhydrous glycerin (Seinhorst, 1959), and examined under a compound microscope for species identification. Nematode identifications were based on the morphology of adult and larval forms. Of special interest, we exclusively presented herein Mesocriconema sphaerocephalum (Taylor, 1936) Loof, 1989 as the first report on bell pepper based on the identification key of Siddiqi (2000) and Geraert (2010).

Photomicrographs of the specimens were made with a Nikon Eclipse Ni compound microscope using a Nikon DS-Ri2 camera. Measurements were made with an ocular micrometer on a Leica WILD MPS48, Leitz DMRB compound microscope.

\section{RESULTS AND DISCUSSION}

Species classification: Our survey recorded M. sphaerocephalum (Taylor, 1936) Loof, 1989 on bell pepper in Al-Seen village, Badr Centre, El-Beheira governorate. $M$. sphaerocephalum was extracted from 5 of $45(11.1 \%)$ soil samples. The density of this nematode was up to 23 individuals/250 g soil. To our knowledge, this is the first report of M. sphaerocephalum on pepper. M. sphaerocephalum is related to the order Tylenchida (Siddiqi, 2000). According to Geraert (2010), it is now under genus Mesocriconema 
Andrassy, 1965 as M. sphaerocephalum (Taylor, 1936) Loof, 1989 with scientific classification as follows:

Tylenchina Chitwood in Chitwood \& Chitwood 1950.

Criconematina Sidiqui 1980.

Criconematiodea Taylor 1936 (1914) (Geraert 1966).

Criconematidae Taylor 1936 (1914).

Criconematinae Taylor 1936 (1914).

Mesocriconema sphaerocephalum (Taylor 1936) Loof 1989.

Synonymization: Mesocriconema sphaerocephalum is a synonym of the following:

Criconemoides sphaerocephalus Taylor, 1936

Macroposthonia sphaerocephala (Taylor, 1936) De Grisse \& Loof, 1965

Criconemella sphaerocephala (Taylor, 1936) Luc \& Raski, 1981

Criconemoides citri Steiner, 1949

Macroposthonia citri (Steiner, 1949) Siddiqi, 1986

Criconemoides georgii Prasad, Khan \& Mathur, 1966

Macroposthonia georgii (Prasad, Khan \& Mathur, 1966) Siddiqi, 1986

\section{Mesocriconema sphaerocephalum (Taylor 1936) Loof \& De Grisse, 1989 Population from Badr Centre, El-Beheira governorate, Egypt.}

\section{(Table 1; Figs. 1-2)}

Description (Females- $\mathrm{n}=10$ ): Individual ring nematodes were hand-picked from nematode suspensions isolated from field samples and examined morphologically for species identification. Morphometric measurements of adult females $(n=10)$ included body length (mean \pm standard deviation $=344.7 \pm 26.9 \mu \mathrm{m}$, range $=300.0-373.0 \mu \mathrm{m}$ ), stylet $(55.4 \pm 0.9,54.0-57.0)$, number of annules from anterior end to excretory pore $(19.3 \pm 2.1,16.0-22.0), \mathrm{V}$ (percentage of length from anterior end to vulva position in total body length: $94.0 \pm 0.5 \%, 93.3-94.5$ ), $\mathrm{R}$ (total body annules:64.0 $\pm 2.1,61.0-$ 67.0), RV (total annules from vulva to tail terminus: $4.2 \pm 0.7,3.0-5.0$ ), Rvan (total annules from anus to tail terminus: $2.5 \pm 0.3,2.0-3.0$ ). Lip region appears truncated to slightly rounded having two annules that are smaller and narrower than other body annules but are not set off. Body annules are round to retrorse with smooth margins, anastomosis many on lateral side forming a sort of zigzag line. Labial disc low, submedian lobes present, small. Stylet robust with well-developed anchor-shaped knobs, vulva on 4-5th annule and anus on 2-3rd annule from the posterior end of the body, and post-vulval body portion conical to more or less rounded, with single lobed terminus. Vagina straight, vulval lips rounded. Spermatheca not seen. Post vulval body portion short, rounded.

The nematode species was identified as Mesocriconema spharerocephalum (Taylor, 1936) Loof \& De Grisse, 1989 based on morphological and morphometric characteristics given by Taylor, 1936 and Raski \& Golden, 1965 re-description. To our knowledge, this is the new host record of the ring nematode (M. sphaerocephalum) associated with bell pepper (Capsicum annuum L.) plants in Badr Centre, El-Beheira governorate, Egypt. 
Table 1. Morphometrics of Mesocriconema spharocephalum (Taylor, 1936) Loof \& De Grisse, 1989 from Egypt. All measurements are in $\mu \mathrm{m}$ and the form: mean \pm s.d. (range).

\begin{tabular}{lcc}
\hline Characters & Females & Juveniles \\
\hline $\mathbf{N}$ & 10 & 5 \\
$\mathbf{L}$ & $344.7 \pm 26.9$ & $349.6 \pm 14.3$ \\
& $(300.0-373.0)$ & $(325-365)$ \\
Stylet & $55.4 \pm 0.9(54.0-57.0)$ & $29.8 \pm 1.32(28.0-32.0)$ \\
V\% & $94 \pm 0.5(93.3-94.5)$ & - \\
R. ex & $19.3 \pm 2.1(16.0-22.0)$ & - \\
R & $64.0 \pm 2.16(61.0-67.0)$ & $71.4 \pm 5.82(63.0-80.0)$ \\
RV & $4.2 \pm 0.7(3.0-5.0)$ & -
\end{tabular}

Males: Not found.

Juveniles $(n=5)$ : Juveniles like females but with shorter stylet, more body annules, and more crenated/retorse annules; anastomoses prominent covering the entire body (Table $1)$.

Other hosts in Egypt: Ibrahim et al. (2000) reported this species but as Criconemella sphaerocephala (Taylor, 1936) Luc \& Raski, 1981 on several other hosts in Egypt. These included Amaranthus caudatus L. (love-lies-bleeding), Conyza linifolia L., Cynodon dactylon L. Pers. (bermudagrass), Cyperus rotundus L. (nutsedge), Dactyloctenium aegyptium L. Richt. (crowfoot grass), Phoenix dactylifera L. (date palm), Portulaca oleracea L. (common purslane), Setaria verticillata L. P. Beauv. (rough bristle-grass). So, we may still report Mesocriconema sphaerocephalum as a new host record (but not a new country record). Moreover, at that time, the genus Criconemella represented one of the largest groups of plant-parasitic nematodes (Barker, 1982 and Ibrahim et al., 2000). That is because prior to the revision by Luc \& Raski (1981), species included in this genus had been placed in six genera: Macroposthonia, Criconemoides, Xenocriconemella, Mesocriconema, Neocriconema, and Madinema.

Current status of ring nematodes: Although the family Criconematidae currently contains 18 genera and five subfamilies (Geraert, 2010), most of them were characterized based on traditional data (Maria et al., 2020). Moreover, a few researchers have obtained low to moderate numbers of criconematids by extraction methods (Baermann funnel, Christie-Perry method) that depend on nematode motility, but in-depth studies of these 
organisms were not initiated until the development and modification of centrifugalflotation (Barker, 1982 and Maria et al., 2020).

Fig.2. Photomicrographs of adult females and juveniles of Mesocriconema sphaerocephalum. A: adult female; B: juvenile; C-D: anterior ends showing head of adult female; E: head of juvenile; F: anterior ends showing esophageal region of adult female; G: posterior end showing vulva and tail region of adult female; H: posterior end showing tail; I: lateral field of adult female showing anastomoses; J: lateral field of juvenile showing anastomoses.

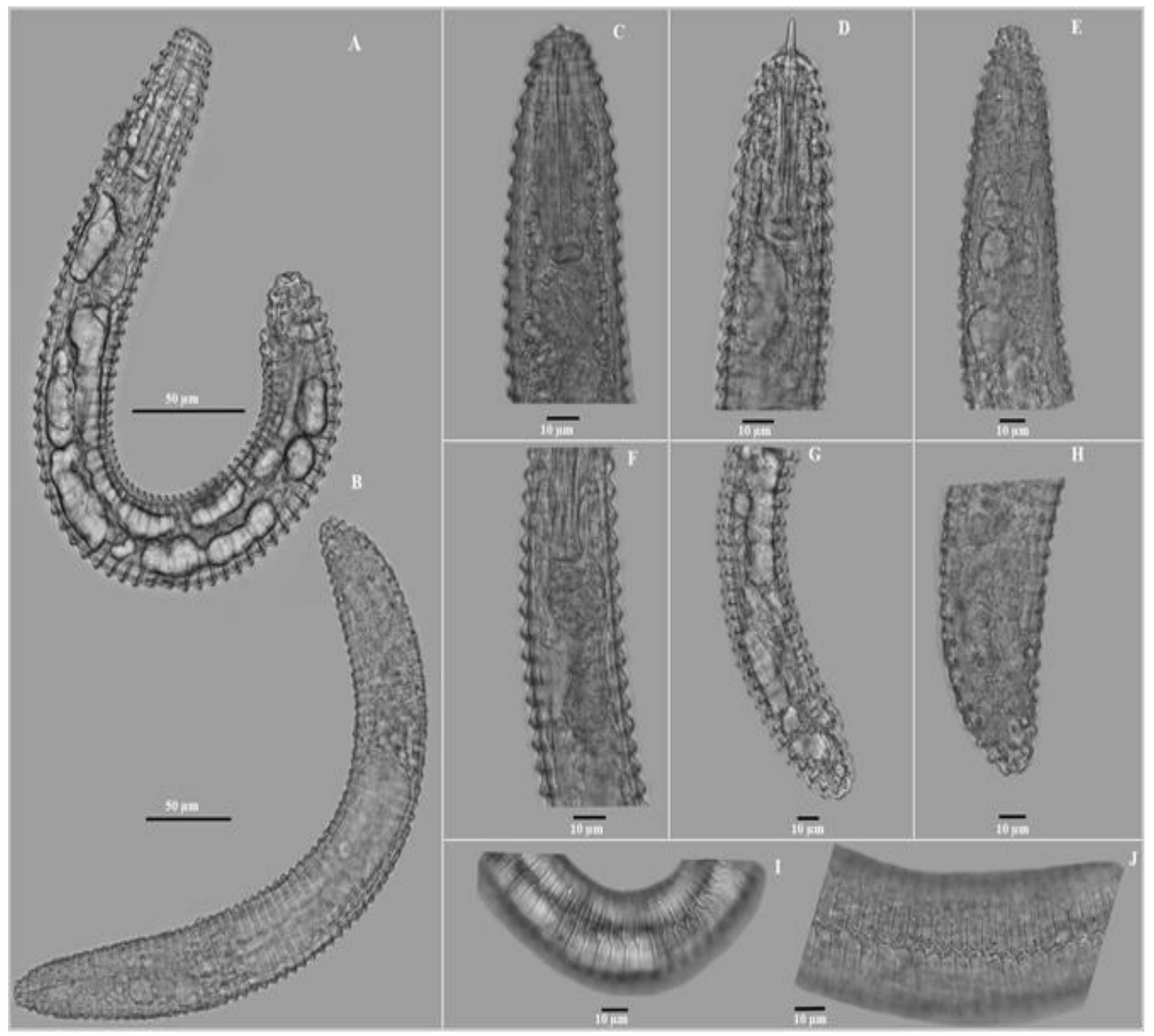

Nevertheless, a few recent investigations could utilize integrative methods; both molecular and classical techniques (e.g. Maria et al., 2018a, b, 2019). As mentioned above, ring nematodes are important ectoparasitic nematodes that can be a potential threat especially at high soil population density. Their ectoparasitic feeding habit is expressed in puncturing the surface of host roots with their rather strong, lengthy stylets. Yet, the limited mobility and ectoparasitic feeding habit of these nematodes are responsible for their being overlooked for a long time as important plant pathogens. 
Nguyen et al. (2019) have recently reported Mesocriconema sphaerocephalum on carrot in Vietnam. Powers et al. (2017) provided the 18S phylogenetic classification of Criconematoidea and discussed the taxonomic placement of several species. More recently, species diversity of ring nematodes of the genus Criconemoides was recently investigated using integrative taxonomy (Maria et al., 2020). Such investigations demonstrated that morphological studies coupled with other recent technological tools are helpful to avoid the previous confusions in generic and species levels and are useful to soundly grasp the phylogenetic relationships of criconematids.

\section{ACKNOWLEDGEMENT}

This study for scientists from Egypt was supported in part by the NRC In-house Project No. 12050105 entitled "Pesticide alternatives against soil-borne pathogens and pests attacking economically important solanaceous crops". One of us (MK) was supported in part by an appointment to the Research Participation Program at the Mycology and Nematology Genetic Diversity and Biology Laboratory USDA, ARS, Northeast Area, Beltsville, MD, administered by the Oak Ridge Institute for Science and Education through an interagency agreement between the U.S. Department of Energy and USDAARS. Facilities offered by both The National Research Centre and Mycology and Nematology Genetic Diversity and Biology Laboratory USDA, ARS, Northeast Area, Beltsville, MD, USA are appreciated.

\section{REFERENCES}

Abd-Elgawad, M.M.M. (2020). Biological control agents in the integrated nematode management of pepper in Egypt. Egypt. J. Biol. Pest. Cont., 30:70 https://doi.org/10.1186/s41938-020-00273-6

Abd-Elgawad, M.M.M.; Eissa, M.F.M.; El-Gindi A.Y.; Smart, G.C. and El-bahrawy, A. (2018). Description and identification of four species of plant-parasitic nematodes associated with forage legumes. Egypt. J. Agronematol., 17(1): 51-64.

Adam, M.; Heuer, H.; Ramadan, E.M.; Hussein, M.A. and Hallmann, J. (2013). Occurrence of plant-parasitic nematodes in organic farming in Egypt. Int. J. Nematol., 23:82-90.

Ayoub, S.M. (1980). Plant nematology, an agricultural training aid. Sacramento, CA: Nema Aid Publications.

Barker K.R. (1982). Criconemella in the Southeastern United States. In: Riggs, R.D. (ed.) Nematology in the Southern Region of the United States. Arkansas Agricultural Experiment Station, Southern Cooperative Services Bulletin 276, Fayetteville, USA, pp 150-156.

Castillo, P. and Gómez, B.A. (1993). Nematodos parásitos de las plantas asociados con cultivos tropicales y subtropicales en el sur de España. Nematol. Medit., 21:45-47.

Coiro, M.I.; Escuer, M.; Agostinelli, A. and Bello, A. (1991). Criconematoidea in vineyards of Conegliano and Valdobbiadene, in the province of Treviso, Italy. Nematol. Medit., 19(1):113-119. 
Escuer, M. and Palomo, A. (1991). Nematodos asociados a melocotoneros, perales y manzanos en el Bajo Cinca (Aragón). Orsis, Barcelona, 6(1):75-81.

Geraert, E. (2010). The Criconematidae of the world: Identification of the family Criconematidae (Nematoda). Ghent: Academia Press.

Handoo, Z.A.; Ibrahim, I.K.A.; Chitwood, D.J. and Mokbel, A.A. (2015). First report of Xiphinema rivesi Dalmasso, 1969 on citrus in northern Egypt. Pak. J. Nematol., 33:161-165.

Ibrahim, I.K.A.; Handoo, Z.A. and El-Sherbiny, A.A. (2000). A Survey of phytoparasitic nematodes on cultivated and non-cultivated plants in Northwestern Egypt. J. Nematol., 32(4S):478-485.

Ibrahim, I.K.A.; Mokbel, A.A. and Handoo, Z.A. (2010). Current status of phytoparasitic nematodes and their host plants in Egypt. Nematropica 40:239-262.

Ibrahim, I.K.A. and Handoo, Z.A. (2016). Occurrence of phytoparasitic nematodes on some crop plants in northern Egypt. Pak. J. Nematol., 34(2):163-169.

Inserra, R.N.; Stanley, J.D.; Ochoa, A.; Schubert, T.S.; Subbotin, S.A., Crow, W.T. and McSorley, R. (2014). Hemicriconemoides species as crop damaging parasitic nematodes in Florida. Nematol. Circ., 223:1-6.

Luc, M. (1970). Contribution à l’étude du genre Criconemoides Taylor, 1936 (Nematoda: Criconematidae). Cahiers ORSTOM, Dunkeque, 11(1):69-131.

Luc, M. and Raski, D.J. (1981). Status of the genera Macroposthonia, Criconemoides, Criconemella and Xenocriconemella (Criconematidae: Nematoda). Rev. Nematol. 4:3-21.

Luna-Guerrero, A.Y.; Montes-Belmont, R.; Talavera-Rubia, M.F.; Flores-Moctezuma, H.E. and Bravo-Luna, Y.L. (2011). Preliminary study of biotic and abiotic factors associated with peach tree death in Morelos, México. Nematropica, 41:254-262.

Maria, M.; Powers, T.O.; Tian, Z.; Harris, T.; Higgins, R. and Zheng, J. (2018a). Description and distribution of three criconematid nematodes from Hangzhou, Zhejiang Province, China. J. Nematol., 50(2):183-206. https://doi.org/10.21307/jofnem-2018-010.

Maria, M.; Cai, R.; Castillo, P. and Zheng, J. (2018b). Morphological and molecular characterisation of Hemicriconemoides paracamelliae sp. n. (Nematoda: Criconematidae) and two known species of Hemicriconemoides from China. Nematology, 20(5):403-422. https://doi.org/10.1163/15685411-00003147.

Maria, M.; Cai, R.; Subbotin, S.A. and Zheng, J. (2019). Description of Discocriconemella sinensis $\mathrm{n}$. sp. (Nematoda: Criconematidae) from the rhizosphere of Camellia sinensis in China. Nematology, 21(8):779-792.

Maria, M.; Miao, W.; Cai, R.; Tian, Z.; Castillo, P. and Zheng, J. (2020). Species diversity of ring nematodes of the genus Criconemoides (Nematoda: Criconematidae) based on three new species from China, using integrative taxonomy. Eur. J. Pl. Pathol. 157:119-139 https://doi.org/10.1007/s10658-020$\underline{01990-2}$

Mckenry, M.V.; Vineros, M. and Teviotdale, B. (1990). Criconema mutabile associated with bacterial canker and Nemaguard rootstock. Pl. Dis. 74(5):394.

Mohamed, M.M.M.; Korayem A.M.; Montasser S.A.; Saeid Ananay A.M. and AlBaghdady, D.M.D. (2017). Phytoparasitic nematodes associated with different 
cultivarsof grape grown in two types of soil in Egypt. Egypt. J. Agronematol., 16(2):85-94.

Nath, R.C.; Sinha, B.C.; Mukherjee, B. and Dasgupta, M. K. (2008). Occurrence, distribution and importance of plant-parasitic nematodes associated with litchi plantations in North Tripura district. Indian J. Nematol., 38:75-80.

Nguyen, T.D.; Nguyen, H.T.; Le, T.M.L.; Tran, T.T.T.; Nobleza, N. and Trinh, Q.P. (2019). First report of Mesocriconema sphaerocephalum (Taylor, 1936) Loof, 1989 associated with carrot (Daucus carota subsp. Stativus) in Vietnam. J. Nematol., 51: DOI: 10.21307/jofnem-2019-048

Peraza-Padilla, W. (2014) First report of two Mesocriconema (Nematoda: Criconematidae) species in mulberry trees in Costa Rica. Pesq. Agropec. Trop., Goiânia, 44(2):223-229. http://www.agro.ufg.br/pat

Powers, T.; Harris, T.; Higgins, R.; Mullin, P. and Powers, K. (2017). An 18S rDNA perspective on the classification of criconematoidea. J. Nematol., 49(3):236-244.

Raski, D. J.; Golden, A.M. (1965). Studies on the genus Criconernoides Taylor, 1936 with descriptions of eleven new species and Bakernema variabile n.sp. (Criconematidae: Nematoda). Nematologica, 11:501-565.

Šály, A. (1976). Fauna of soil nematodes in the water work region Liptovská Mara. Acta Facultatis Rerum Naturalium Universitatis Comenianae Zoologia, Liptovská Mara, 20(1): 5-21.

Seinhorst, J.W. (1959). A rapid method for the transfer of nematodes from fixative to anhydrous glycerine. Nematologica, 4:67-69.

Siddiqi, M.R. (2000). Tylenchida parasites of plants and insects. Wallingford: CABI Publishing.

Westerdahl, B.B. and Duncan, R.A. (2015). Peach nematodes. UC Pest management guidelines (updated 9/15). UCIPM University of California Agriculture and Natural Resources, Statewide Integrated Pest Management Program. http://ipm.ucanr.edu/PMG/r602200111.html

Yousef, D.M. and S'Jacob, J.J. (1994). A nematode survey of vegetable crops and some orchards in the Ghor of Jordan. Nematol. Medit., 22(1):11-15.

Zayed, G.A.; Abdo, A.A.; Hammam, H.B. and Khafagi, E.Y. (2017) Cultivation and production of pepper and eggplant in Egypt. Technical issue No. 15, General Administration of Agricultural Culture, Ministry of Agriculture, Egypt. 


\title{
الملخص العربى
}

\author{
التقرير الأول للنوع النيماتودي Mesocriconema sphaerocephalum علي نبات الفلفل الرومي في مصر \\ زافار هندو ${ }^{1}$ - ميهيل كانتر ${ }^{1}$ - مصطفي همام² - معوض محمد² - محفوظ عبد الجواد² \\ 1-معمل التتوع الوراثي والبيولوجي لعلوم الفطر والنيماتودا، وزارة الزراعة الأمريكية ، مركز البحوث الزراعية في بلتسفيل، \\ ميريلاند، الولايات المتحدة الأمريكية. \\ 2-قسم أمراض النبات ـ المركز القومى للبحوث ـ الاقى 12622 ـ الجيزة ـ مصر
}

تشكل النيماتودا ـ الديدان الإسطو انية ـ التابعة للجنس Mesocriconema مجموعة من الديدان الحلقية

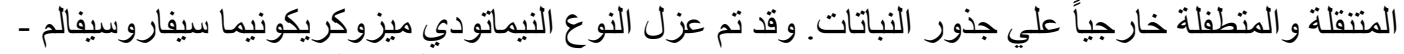
Mesocriconema sphaerocephalum -

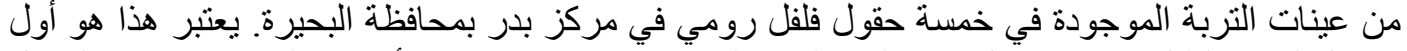

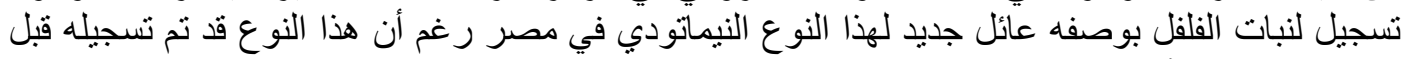

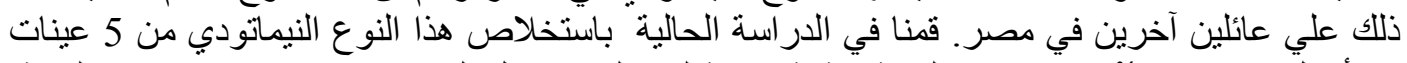

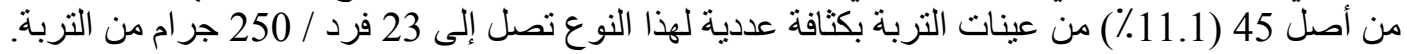

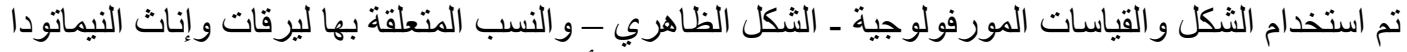
لتحديد هذا النوع. عرض البحث معلومات إضافية عن توزيع و أهمية وحالة هذا الطفيل النباتي.

الكلمات المفتاحية: نبات عائل، الثكل الظاهري ، نيماتودا حلقية ، مصر ، وصف الأنواع ، حصر. 